\title{
KARAKTERISTIK POLA IRINGAN GRUP MUSIK REBANA AL-ISTIQOMAH KABUPATEN KEBUMEN
}

\author{
Afiin Fitri Millatin \\ Pascasarjana, Universitas Negeri Yogyakarta \\ Email:millatinafiin@gmail.com
}

\begin{abstract}
Abstrak
Perkembangan musik rebana di Indonesia khususnya di tanah Jawa mulai menjadi tradisi lokal yang dilestarikan. Setiap daerah atau kabupaten memiliki ciri khas masing-masing dalam segi permainan alat musik rebana. Grup rebana Al-Istiqomah merupakan sebuah kelompok musik yang menyajikan pertunjukan musik islami khususnya kesenian rebana. Seiring berkembangnya zaman supaya lebih diminati masyarakat, pelatih grup rebana Al-Istiqomah mengaransemen lagu-lagu yang dimainkan serta membuat beberapa variasi pada pola iringan rebana supaya lebih diingat masyarakat dan menjadi ciri khas grup rebana Al-Istiqomah. Penelitian ini menggunakan pendekatan kualitatif deskriptif. Sumber data berasal dari observasi, wawancara, dan dokumentasi. Hasil penelitian karakteristik pola iringan rebana terdapat beberapa variasi pola iringan pada instrumen genjring A,B,C serta variasi pola iringan alat musik rebana pada intro, tema lagu, interlude, dan coda.
\end{abstract}

Kata Kunci: Karakteristik, Pola Iringan, Rebana

\section{CHARACTERISTICS OF ACCOMPANIMENT PATTERNS OF AL-ISTIQOMAH REBANA MUSIC GROUP IN KEBUMEN DISTRICT}

\begin{abstract}
The development of rebana music in Indonesia especially in Java becomes a preserved local tradition. Each region or district has its own characteristics in terms of playing a rebana musical instrument. Al-Istiqomah rebana group is a music group that presents Islamic musical performances, especially rebana art. As the times evolved to be more attractive to the public, the coach of the Al-Istiqomah rebana group arranged the songs that were played and made several variations on the rebana accompaniment pattern to make them more memorable to the public and became a hallmark of the Al-Istiqomah rebana group. This research uses a descriptive qualitative approach. Data sources come from observations, interviews, and documentation. The results of the research on the characteristics of rebana accompaniment patterns there are several variations of accompaniment patterns on the genjring instruments A, B, C as well as variations of rebana accompaniment patterns on the intro, theme song, interlude, and coda.
\end{abstract}

Keywords: Characteristic, Accompaniement pattern, Rebana

\section{PENDAHULUAN}

Kebudayaan pada dasarnya merupakan segala macam bentuk gejala kemanusiaan, baik yang mengacu pada sikap, konsepsi, ideologi, perilaku, kebiasaan, karya kreatif dan sebagainya (Maryaeni, 2005: 5). Indonesia adalah negara kepulauan dengan berbagai macam kebudayaan serta kesenian baik seni asli, seni baru, maupun seni campuran antar keduanya 
Kesenian rebana merupakan salah satu kesenian yang berkembang di Indonesia tetapi bukan berasal asli dari Indonesia. Kesenian rebana datang dari dataran Timur Tengah yang merupakan kesenian musik di mana lagulagunya banyak mengandung unsur-unsur dakwah Islamiyah dan nasihat-nasihat baik sesuai ajaran agama Islam (Sutiyono, 2014: 91). Lagu-lagu kesenian rebana biasanya dinyanyikan dengan irama penuh kegembiraan yang hampir menyerupai irama-irama Timur Tengah dengan diiringi rebana, yaitu sejenis alat musik tradisional berupa kendang satu sisi dengan badan tidak rendah sesuai dengan kemampuan genggaman tangan, termasuk dalam keluarga frame-drum sejenis tambourin, baik dengan kericikan atau tanpa kericikan (Banoe; 2003: 353). Terbang dalam bahasa Jawa banyak dikenal di berbagai wilayah dalam pengaruh kebudayaan Islam yang merupakan perangkat alat musik qasidah.

Kesenian rebana lahir bersamaan dengan kelahiran Islam, untuk pertama kalinya, rebana ditampilkan oleh kaum Anshar (penolong Nabi Muhammad SAW) dan sahabat-sahabtanya dari kaum Muhajirin dalam perjalanan hijrah dari tanah kelahirannya (Makkah) ke Yastrib (Madinah) di mana pada saat itu beberapa kaum Anshar menyambut kedatangan Rasulullah SAW dan mendendangkan lagu-lagu pujian atau sholawat Nabi Muhammad SAW yang diiringi dengan lantunan alat musik rebana. Lagu-lagu pujian atau sholawatan saat ini melegenda ke seluruh penjuru dunia dan semua umat Islam sekarang dapat menikmatinya (Siti Maemonah, 2015: 2).

Grup rebana Al-Istiqomah merupakan sebuah kelompok musik yang menyajikan pertunjukan musik islami khususnya kesenian rebana. Grup ini terbentuk sejak tahun 2015 yang diprakarsai oleh ibu $\mathrm{Hj}$. Atun Sahdiyati Machful atau Ibu Machful. Ibu Machful merupakan pendiri sekaligus penasihat dari grup rebana Al-Istiqomah Kabupaten Kebumen. Umumnya seni rebana yang sangat kental dengan nilai-nilai nasihat baik sesuai ajaran Islam itu dipopulerkan oleh kalangan ulama pesantren, namun di dusun Kauman justru dikembangkan serta dipopulerkan oleh sekelompok ibu-ibu yang berasal dari kelompok jamaah putri Masjid Agung di RW 2 Kauman, desa Kutosari, kabupaten Kebumen.

Al-Istiqomah memiliki makna yaitu supaya para anggota dari grup rebana dapat berdiri pada jalan yang lurus dalam mensyiarkan agama Islam melalui seni (Sutiyono, 2015: 78). Seiring berkembangnya zaman dan supaya lebih diminati masyarakat, pelatih grup rebana Al-Istiqomah mengaransemen lagulagu yang dimainkan serta membuat beberapa variasi pada pola iringan rebana supaya lebih diingat masyarakat dan menjadi ciri khas grup rebana Al-Istiqomah. Oleh karena itu, peneliti tertarik untuk mengkaji lebih dalam mengenai karakteristik pola iringan grup musik rebana Al-Istiqomah kabupaten Kebumen.

\section{KAJIAN TEORITIK}

\section{Pengertian Karakteristik}

Karakteristik yaitu ukiran atau pahatan watak atau jiwa sehingga berbentuk unik, khas, menarik, dan berbeda atau dapat dibedakan dengan yang lain (John, 2010: 1). Karakteristik berarti sifat khas, sesuai dengan tabiat atau coraknya, ciri khas, dan watak (Faridan, 2012: 8). Hal tersebut sama dengan pendapat Thoifin (1992 : 72), yang mengatakan bahwa karakteristik mempunyai sifat khas yang tidak dapat disembunyikan. Dari beberapa pendapat tersebut dapat disimpulkan bahwa karakteristik adalah suatu ukiran atau pahatan watak ataujiwa yang khas sesuai dengan tabiat atau coraknya namun juga tidak dapat disembunyikan. Karena umumnya sesuatu yang khas, unik dan menonjol itu disebut karakteristik dan sesuatu yang berkarakter itu akan selalu dikenal oleh semua orang berkat keunikannya.

\section{Pola Iringan}

Supanggah (2009: 248) berpendapat bahwa pola adalah istilah generik untuk menyebut satuan tabuhan dengan ukuran panjang tertentu dan yang telah memiliki kesan atau karakter tertentu. Adapun iringan menurut Tambajong (1992: 245) berasal dari kata iring, yaitu istilah yang digunakan dalam bahasa Indonesia 
untuk memadankan dengan akompanimen, yaitu musik instrumen yang melatari vokal, tetapi istilah ini sering kali dipakai juga untuk mengartikan suatu sajian musik tradisional Indonesia, yang dimainkan untuk mengarak atau menghormati tamu pengantin, dan khitanan.

\section{Musik}

Musik adalah suatu susunan suara yang harmonik dan dibunyikan pada aturan waktu tertentu dan berdasarkan waktu tertentu (Rudiyanto dalam Suseno, 2005: 13). Menurut Jamalus (1988: 1) musik adalah suatu karya seni bunyi dalam bentuk lagu atau komposisi musik yang mengungkapkan pikiran dan perasaan penciptanya melalui unsur-unsur musik yaitu irama, melodi, harmoni, bentuk atau struktur lagu, dan ekspresi sebagai satu kesatuan. Pengertian lainnya yaitu musik adalah ungkapan rasa indah manusia dalam bentuk suatu konsep pemikiran yang bulat, dalam wujud nada-nada atau bunyi-bunyi lainnya yang mengandung ritme, harmoni, serta mempunyai bentuk dalam ruang dan waktu (Sudarsono, 1992: 1).

Lebih lanjut dibahas oleh Myers (2004: 40), mengelompokkan instrumen musik berdasarkan sumber bunyinya menjadi lima, yaitu :

a. Idiophone

Instrumen musik yang sumber bunyinya dihasilkan dari alat itu sendiri.

Contoh : gong, marimba, glockenspiel.

b. Aerophone

Instrumen musik yang sumber bunyinya dihasilkan dari udara atau ditiup. Contoh : recorder, flute, piccolo, serompet.

c. Chordhophone

Instrumen musik yang sumber bunyinya dihasilkan dari dawai.

Contoh : gitar, harpa, piano, sitar.

d. Membranophone

Instrumen musik yang sumber bunyinya dihasilkan dari membran atau kulit. Contoh: drum, timpani, kendang.

\section{e. Electrophone}

Instrumen musik yang sumber bunyinya dihasilkan dari gelombang listrik. Contoh : gitar elektrik, synthesizer, stage piano.

\section{Unsur-Unsur Musik}

Musik terdiri dari tiga aspek utama, yaitu: melodi, ritme atau irama, dan harmoni. Dapat dijelaskan bahwa musik dapat terdiri dari tiga unsur tersebut.

a. Melodi

Melodi merupakan susunan rangkaian nada (bunyi dengan getaran teratur) yang terdengar berurutan serta berirama dan mengungkapkan suatu pikiran dan perasaan (Jamalus, 1988: 16). Menurut Joseph (2005: 58) gerak nada-nada dalam melodi dibagi menjadi 2 macam yaitu gerak melangkah dan gerak melompat. Gerak melangkah yaitu gerak nada ke nada lain yang berurutan. Gerak nada melodi melangkah dibedakan menjadi 2 yaitu gerak melangkah naik dan turun. Gerak melodi melangkah memberikan kesan rasa tenang. Gerak melompat adalah gerak nada ke nada lain yang tidak berurutan, gerak nada melodi melompat dibedakan juga menjadi 2 yaitu gerak melompat naik dan turun. Gerak melodi melompat memberikan kesan rasa tegang. Adanya beberapa teori tersebut dapat disimpulkan bahwa melodi adalah sebuah serangkaian nada yang membentuk sebuah gagasan atau ide yang mempunyai tinggi rendah dan panjang pendek nada.

b. Ritme atau Irama

Jamalus (1988: 56) berpendapat bahwa irama berhubungan dengan panjang pendeknya not dan berat ringannya tekanan atau aksen pada not. Namun demikian, oleh teraturnya gerak maka irama tetap dapat dirasakan meskipun melodi diam. Dan keteraturan gerak ini menyebabkan lagu lebih indah didengar dan dirasakan. Irama merupakan pola ritme yang dinyatakan dengan nama, seperti walts, mars, bossanova dan lain-lain, irama tercipta dari bunyi diam menurut lama waktu yang 
telah ditentukan (Banoe, 2003: 198). Dari beberapa pendapat tersebut irama bisa diartikan sebagai ketukan yang memiliki nilai nada atau durasi yang mengalir teratur mengikuti gerak melodi. Penakanan atas sebuah nada untuk membuatnya menjadi aksen dan mempunyai panjang pendak nada yang disebut durasi. Keteraturan gerak ini yang menyebabkan musik lebih indah didengar dan dirasakan.

c. Harmoni

Harmoni adalah elemen musikal yang didasarkan atas penggabungan secara simultan dari nada-nada. Jikalau melodi adalah sebuah konsep horizontal, harmoni adalah konsep vertikal (Hugh M. Miller, 2017: 39). Menurut Jamalus (1988: 30), harmoni atau paduan nada ialah bunyi gabungan dua nada atau lebih, yang berbeda tinggi rendahnya dan dibunyikan secara serantak. Dasar dari paduan nada tersebut ialah trinada. Menurut Banoe (2003: 180), mengartikan harmoni sebagai cabang ilmu pengetahuan musik yang membahas dan membicarakanperihalkeindahankomposisi musik. Berdasarkan beberapa pendapat tersebut dapat disimpulkan bahwa harmoni adalah elemen musikal yang digabunggabungkan antara beberapa nada yang berbeda tinggi randahnya dan dibunyikan secara bersama-sama yang menghasilkan keindahan komposisi musik.

\section{Rebana}

Rebana merupakan salah satu dari sekian banyak seni tradisional yang ada di berbagai daerah Indonesia yang bernafaskan keislaman. Pengertian rebana menurut Jaelani (2007: 175) berasal dari kata rabbana yang berarti wahai tuhan kami (satu doa dan pujian terhadap tuhan). Istilah hadrah juga sering disebut, rebana, trebang, sadrah. Rebana pada awalnya adalah sebagai instrumen dalam menyanyikan lagu keagamaan berupa puji-pujian terhadap Allah SWT dan para Rasulnya.

Dalam kesenian juga terdapat alat musik yang selalu digunakan untuk mengiringi, salah satunya yaitu alat musik terbang. Terbang adalah semacam alat musik pukul sejenis gendang atau ketipung atau gendrang, yang dipukul dengan tangan. Jenis terbang ada dua macam yaitu: terbang pelamutan atau pemadihinan dan terbang sinoman hadrah. Terbang pemadihinan, terbang pelamutan, terbang sinoman hadrah dan terbang ampat mempunyai fungsi dan kegunaan yang hampir sama pula, yaitu sebagai pengatur irama dalam permainannya (Siti \& Sutiyono, 2017: 97 112).

Seni rebana mengandung nilai-nilai religius, etika, dan norma ajaran yang diduga dapat menjadi salah satu alternatif untuk membantu mengatasi krisis moral bangsa Indonesia dewasa ini. Menurut Miranda Risang Ayu (1996: 35) bahwa seni rebana tidak hanya dilestarikan oleh komunitas pendukungnya di pesantren, melainkan juga telah dikembangkan menjadi seni komersial yang mampu memberikan kontribusi bagi kelangsungan hidup pendukungnya, baik secara sosial, politik, ekonomi, dan budaya.

Pada saat kesultanan Demak menguasai seluruh Jawa dan sebagian luar Jawa, bersama dengan agama Islam masuk Indonesia pula alat musik Arab misalnya rebana, rebab, gambus (Prier, 1991: 81). Rebana adalah alat musik tradisional berupa kendang satu sisi dengan badan tidak rendah sesuai dengan kemampuan genggaman tangan, termasuk dalam keluarga frame drum sejenis tamborin (Banoe, 2003: 353). Menurut M. Soeharto (1978: 214) ada beberapa jenis rebana dibedakan dari ukurannya, yaitu :

a. Rebana Besar; biasa disebut rebana biang, terbang gede atau terbang indung atau terbang gong.

b. Rebana Sedang; sering disebutterbang dara, terbang gembyung atau juga suwukan.

c. Rebana kecil; sering disebut rebana ketimpring, genjring atau juga thung / theng.

Alat musik rebana sering dipakai untuk meramaikan suasana dalam suatu hajatan atau kepentingan pada masyarakat Jawa dimana para penyanyi bernyanyi bersama sambil memainkan alat musik rebana dan 
membawakan lagu bernuansa Islam dengan tujuan melantunkan pujian kepada Allah SWT dan Nabi Muhammad SAW. Pada saat pertunjukan rebana dimulai dengan nyanyian, rebana ditabuh dengan lembut dengan pola permainan yang diulang-ulang. Ketika sudah memasuki jeda atau interlude lagu permainan rebana ditabuh dengan keras dengan pola saling bersahutan namun tetap harmonis.

\section{HASIL DAN PEMBAHASAN}

\section{A. Hasil}

\section{Pola Iringan Instrumen Grup Musik Rebana Al-Istiqomah}

Grup rebana Al-Istiqomah memiliki berbagai macam instrumen iringan yang terbagi dalam 2 macam kelompok yaitu, instrumen ritmis atau instrumen tidak bernada dan instrumen melodis.

1. Instrumen ritmis atau instrumen tidak bernada

\section{a. Genjring}

Genjring merupakan bagian alat musik rebana yang termasuk dalam kelompok jenis membranophone berbentuk lingkaran. Menurut hasil wawancara dengan Bapak Agus Sumanto selaku pelatih dan pemain grup musik rebana Al-Istiqomah (10 Desember 2019).

"Pola iringan setiap alat itu bedabeda mbak, ada juga yang bervariasi. Contohnya genjring itu saya buat 3 pola iringan supaya lebih bervariasi. Jadi satu lagu, satu pola iringan genjring. Kalo alat yang lain pola iringannya ya tetep satu saja tapi nanti paling divariasi di intro atau interlude sama ending."

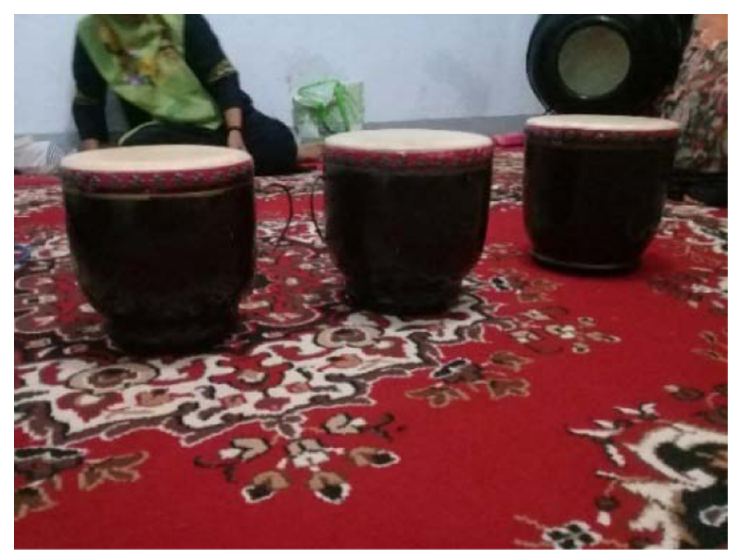

Gambar 1 : Instrumen Genjring (Dok. Afiin F M, 2019)

Instrumen genjring rebana AlIstiqomah terdapat 3 (tiga) pola iringan. Setiap 1 (satu) lagu hanya memainkan 1 (satu) macam pola iringan. Pada pola iringan A pola ritmis genjring birama 2 di ketukan ke 2 up terdapat notasi 1/16. Pada pola iringan B pola ritmis genjring disetiap ketukan up terdapat notasi $1 / 16$, dan pada pola iringan $C$ pola ritmis genjring di ketukan pertama up dan ketiga up terdapat notasi 1/16. Selain ketiga pola iringan genjring tersebut terdapat variasi permainan yang telah di aransemen dan dimainkan pada bagian intro, interlude dan ending. Genjring dimainkan hampir di seluruh bagian lagu kecuali pada bagian melodi lagu yang dinyanyikan oleh vokal utama.

b. Ketiplak

Ketiplak merupakan bagian alat musik rebana yang termasuk dalam kelompok jenis membranophone berbentuk tabung. Instrumen ketiplak berbeda dengan genjrig yaitu ada satu dan memungkinkan adanya variasi hanya pada pemain ketiplak 1 saja. Pemain ketiplak pada grup rebana AlIstiqomah terdapat 3 (tiga) orang yang terbagi menjadi ketiplak 1, ketiplak 2, dan ketiplak 3. Setiap pemain ketiplak memainkan pola iringannya masingmasing sesuai pola yang telah diajarkan 
sehingga menghasilkan harmoni irama ritmis pada iringan rebana. Ketiplak dimainkan hanya pada bagian melodi lagu yang dinyanyikan oleh vokal utama.

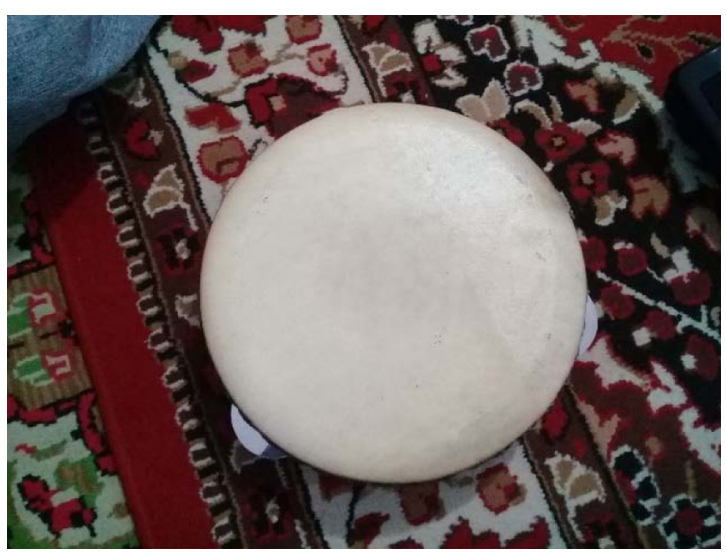

Gambar 2: Instrumen Ketiplak

(Dok. Afiin F M, 2019)

c. Gendong

Gendong merupakan alat musik pukul pada rebana yang termasuk dalam kelompok jenis membranophone berbentuk tabung besar. Alat ini mempunyai 3 macam jenis gendong dengan ukuran yang berbeda-beda. Gendong berukuran kecil mempunyai diameter 40-45 cm, gendong ukuran sedang mempunyai diameter 55-56 $\mathrm{cm}$, dan gendong berukuran besar mempunyai diameter $65-70 \mathrm{~cm}$.

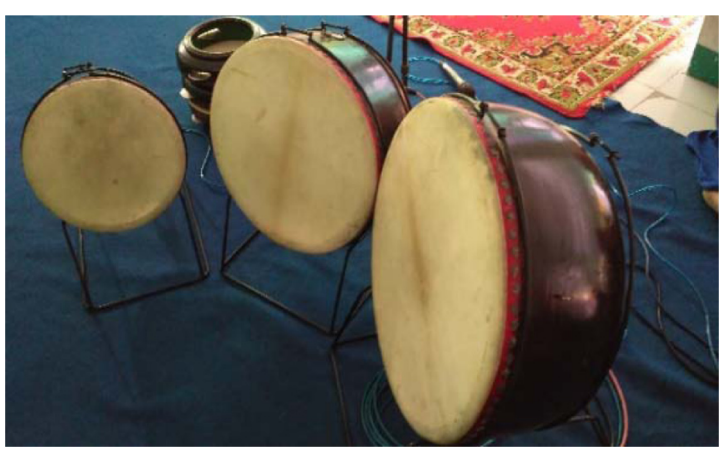

Gambar 3 : Instrumen Gendong (Dok. Afiin F M, 2019)

Pola iringan instrumen gendong hanya ada satu namun pada intro, interlude dan ending terdapat variasi permainan sesuai dengan lagu yang telah diaransemen. Peran instrumen gendong sangat penting dalam grup rebana Al-Istiqomah yaitu sebagai pemain ritmis paling utama sehingga gendong dimainkan pada semua bagian lagu mulai dari intro hingga ending lagu.

d. Tamborin tanpa membran dan bermembran

Tamborin merupakan bagian alat musik rebana yang termasuk dalam kelompok jenis membranophone berbentuk lingkaran yang di sekeliling sisinya terdapat cymbal kecil dan idiophone yang bentuknya setengah lingkaran tanpa ada penutup dari membran plastik namun tetap di sekelilingnya terdapat cymbal kecil. Menurut hasil wawancara dengan Bapak Agus Sumanto selaku pelatih dan pemain grup musik rebana Al-Istiqomah (10 Desember 2019).

"tamborin ini tugasnya beda-beda, yang nggak ada membrannya ikut permainan ritmis lagunya aja trus yang ada membran ikut main pas ketiplak main aja."

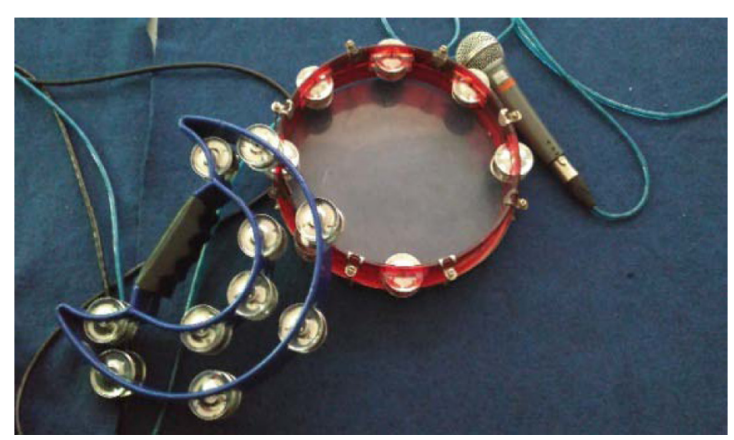

Gambar 4 : Instrumen Tamborin Tanpa

Membran dan Bermembran (Dok. Afiin F M, 2019)

Pola iringan instrumen tamborin tanpa membran terdapat variasi pada intro, interlude, dan ending. Sedangkan pola iringan pada instrumen tamborin bermembran hanya ada satu yaitu 
dengan cara memukul 2 (dua) kali bagian membran pada satu ketukan lalu menggetarkan membran tamborin menggunakan ibu jari selama satu ketukan selanjutnya kembali diulangulang. Peran instrumen tamborin juga sangat penting dalam grup rebana Al-Istiqomah yaitu sebagai pemain ritmis kedua setelah gendong sehingga tamborin dimainkan hampir pada semua bagian lagu kecuali pada tamborin bermembran hanya dimainkan bersamaan dengan ketiplak saja.

\section{Instrumen melodis}

a. Keyboard

Keyboard merupakan bagian alat musik rebana yang termasuk dalam kelompok jenis electrophone. Keyboard berfungsi sebagai pengiring melodis. Iringan instrumen keyboard pada rebana ada dua macam. Pertama yaitu sebagai pengiring melodis secara utuh di intro dan interlude lagu. Kedua sebagai pengiring vokal dengan akorakor yang sudah ada pada lagu.

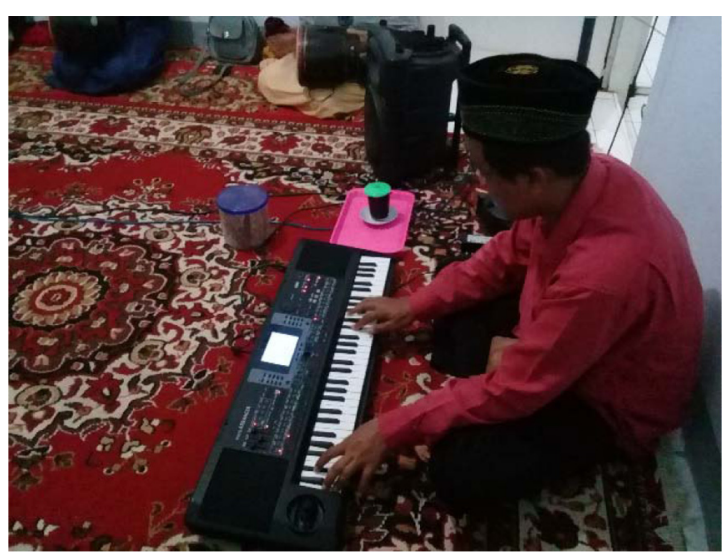

Gambar 5 : Instrumen Keyboard (Dok. Afiin F M, 2019)

Pola iringan instrumen keyboard pada rebana Al-Istiqomah menggunakan melodi minor harmonis. Selain memainkan melodi pada bagian intro dan interlude, keyboard juga memainkan filler melodi dengan improvisasi pada bagian vokal sebagai melodi utama. Sedangkan pada permainan akor menggunakan pola sinkop atau dibunyikan pada ketukan up (naik).

b. Vokal

Vokal merupakan bagian alat musik rebana yang termasuk dalam kelompok jenis idiophone. Vokal berfungsi sebagai pemain melodi utama lagu. Dalam grup rebana instrumen vokal terdiri dari vokal utama dan backing vokal. Vokal utama berperan menyanyikan melodi utama dari awal sampai akhir lagu. Sedangkan backing vokal hanya menyanyikan bagian reff lagu secara bersama-sama.

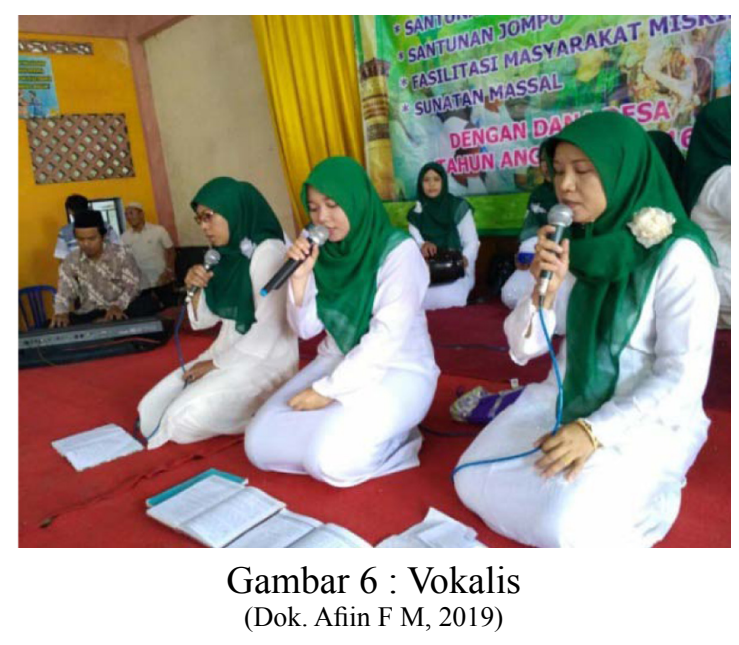

Pada umumnya jumlah pemain vokal dalam grup rebana ada tiga sampai empat orang yang terbagi menjadi vokal utama terdiri dari satu orang dan backing vokal terdiri dari dua sampai tiga orang. Melodi vokal pada rebana Al-Istiqomah menggunakan tangganada minor harmonis. Terdapat variasi pembagian suara saat backing vokal ikut bernyanyi dengan vokal utama pada tema II lagu. 


\section{B. Pembahasan}

\section{Karakteristik Pola Iringan Grup Rebana Al-Istiqomah}

Pada penelitian yang berjudul "Karakteristik Pola Iringan Grup Musik Rebana Al-Istiqomah Kabupaten Kebumen" ini peneliti telah menganalisis 3 (tiga) contoh lagu yang sudah diaransemen oleh pak Agus Sumanto yaitu Ya Wazir, Sholawat Badar, dan An Nabi dengan perbandingan penggunaan pola iringan genjring yang berbeda yaitu antara pola iringan genjring A pada lagu Sholawat Badar, pola iringan genjring B pada lagu Ya Wazir, dan pola iringan genjring $\mathrm{C}$ pada lagu An Nabi.
Pada aransemen lagu Ya Wazir terdiri dari 3 (tiga) bagian yaitu Intro, bagian A, bagian $A \square$, interlude, bagian B, dan sepanjang lagu Ya Wazir dimainkan instrumen genjring memainkan pola iringan B. Intro lagu Ya Wazir melodi utama dimainkan oleh keyboard dan adanya variasi permainan pada instrumen genjring, tamborin tanpa membran dan gendong dari birama 2 sampai birama 8. Pada bagian A vokal menyanyikan melodi utama lagu dari birama 9 sampai birama 24. Keyboard pada bagian ini berpindah peran sebagai akompanyemen dan memainkan filler improvisasi serta adanya transisi permainan instrumen ritmis dari genjring pada intro berpindah ke insturmen ketiplak bersamaan dengan masuknya tamborin bermembran.

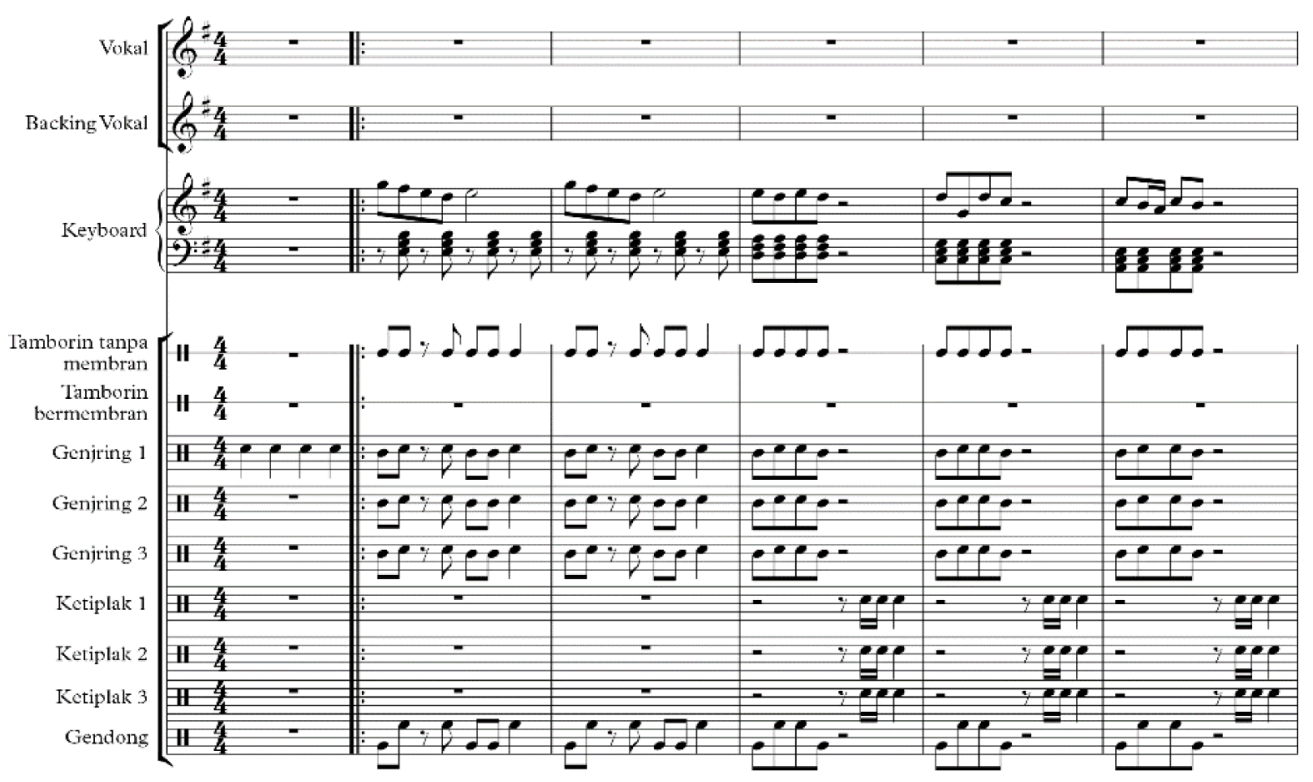

Gambar 7 : Intro Pada Lagu Ya Wazir (Dok. Afiin F M, 2019)

Selanjutnya bagian A $\square$ merupakan tema lagu yang sama dengan bagian A namun terdapat variasi pada backing vokal dan adanya transisi permainan dari instrumen ketiplak ke insturmen genjring. Instrumen genjring memainkan pola iringan B dari birama 25 sampai birama 40. Setelah itu masuk menuju interlude dimana keyboard memainkan melodi utama dari birama 41 sampai birama 54 serta terdapat variasi pola iringan pada instrumen genjring dan gendong. Pada bagian B, vokal utama masuk menyanyikan melodi utama diiringi oleh instrumen ritmis serta keyboard yang memainkan akor dan menambahkan filler improvisasi dari birama 55 sampai birama 64 selanjutnya kembali lagi menuju bagian $\mathrm{A} \square$ hingga bagian B dan ending lagu berada di bagian $\mathrm{A} \square$.

Pada aransemen lagu Sholawat Badar terdiri dari 3 (tiga) bagian yaitu Intro, bagian $\mathrm{A}$, bagian $\mathrm{A} \square$, interlude, bagian $\mathrm{B}$, dan coda. Sepanjang lagu Sholawat Badar dimainkan, 
instrumen genjring memainkan pola iringan A. Pada Intro lagu Sholawat Badar melodi utama dimainkan oleh keyboard dan adanya variasi permainan pada instrumen genjring, tamborin tanpa membran dan gendong dari birama 2 sampai birama 12. Pada bagian A vokal menyanyikan melodi utama lagu dari birama
13 sampai birama 33. Keyboard pada bagian ini berpindah peran sebagai akompanyemen dan memainkan filler improvisasi serta adanya transisi permainan instrumen ritmis dari genjring pada intro berpindah ke insturmen ketiplak bersamaan dengan masuknya tamborin bermembran.

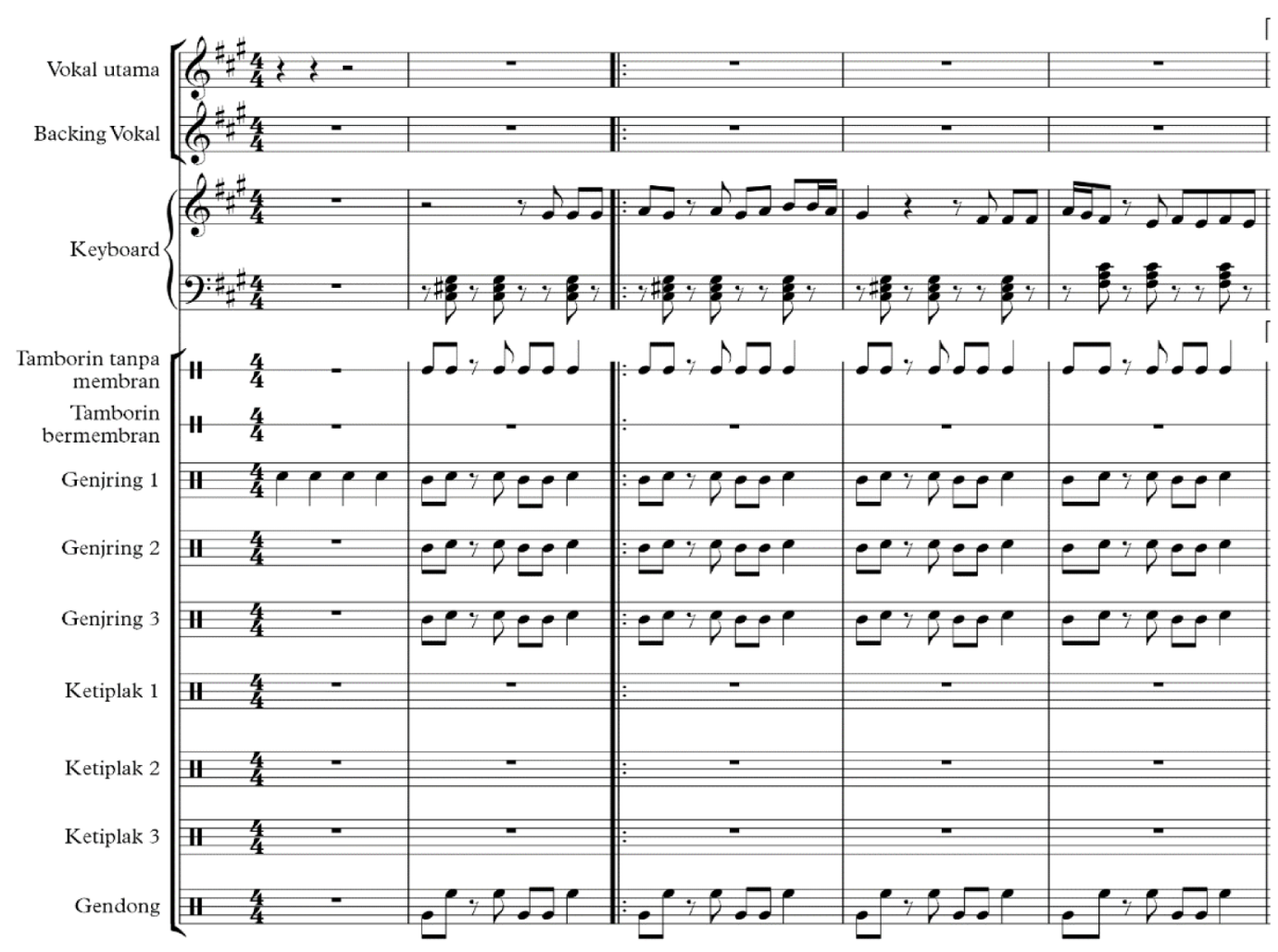

Gambar 8 : Intro Pada Lagu Sholawat Badar (Dok. Afiin F M, 2019)

Selanjutnya bagian $\mathrm{A} \square$ merupakan tema lagu yang sama dengan bagian A namun terdapat variasi pada backing vokal dan adanya transisi permainan dari instrumen ketiplak ke insturmen genjring mulai birama 34 sampai birama 54. Setelah itu masuk menuju interlude dimana keyboard memainkan melodi utama dan terdapat variasi pola iringan pada instrumen genjring dan gendong dari birama 55 sampai birama 61. Pada bagian B, vokal utama masuk menyanyikan melodi utama diiringi oleh instrumen ritmis serta keyboard yang memainkan akor dan menambahkan filler improvisasi dari birama 62 sampai birama 75 serta terdapat variasi permainan pada instrumen genjring dan ketiplak 1 pada birama 70 .
Berbeda dengan lagu Ya Wazir, pada lagu Sholawat Badar terdapat coda setelah pengulangan 2 (dua) kali dari bagian B menuju bagian A $\square$ hingga ending di coda. Pada coda keyboard memainkan melodi utama untuk menutup lagu dari birama 76 sampai birama 79 dan terdapat variasi permainan pada instrumen genjring dan gendong.

Pada aransemen lagu An Nabi terdiri dari 3 (tiga) bagian yaitu Intro, bagian $\mathrm{A}$, bagian $\mathrm{A} \square$, interlude, bagian B, dan coda. Sepanjang lagu An Nabi dimainkan, instrumen genjring memainkan pola iringan C. Pada Intro lagu An Nabi melodi utama dimainkan oleh keyboard dan adanya variasi permainan pada 
instrumen genjring, tamborin tanpa membran dan gendong dari birama 2 sampai birama 10 . Pada bagian A vokal menyanyikan melodi utama lagu dari birama 11 sampai birama 19 . Keyboard pada bagian ini berpindah peran sebagai akompanyemen dan memainkan filler improvisasi serta adanya transisi permainan instrumen ritmis dari genjring pada intro berpindah ke insturmen ketiplak bersamaan dengan masuknya tamborin bermembran.

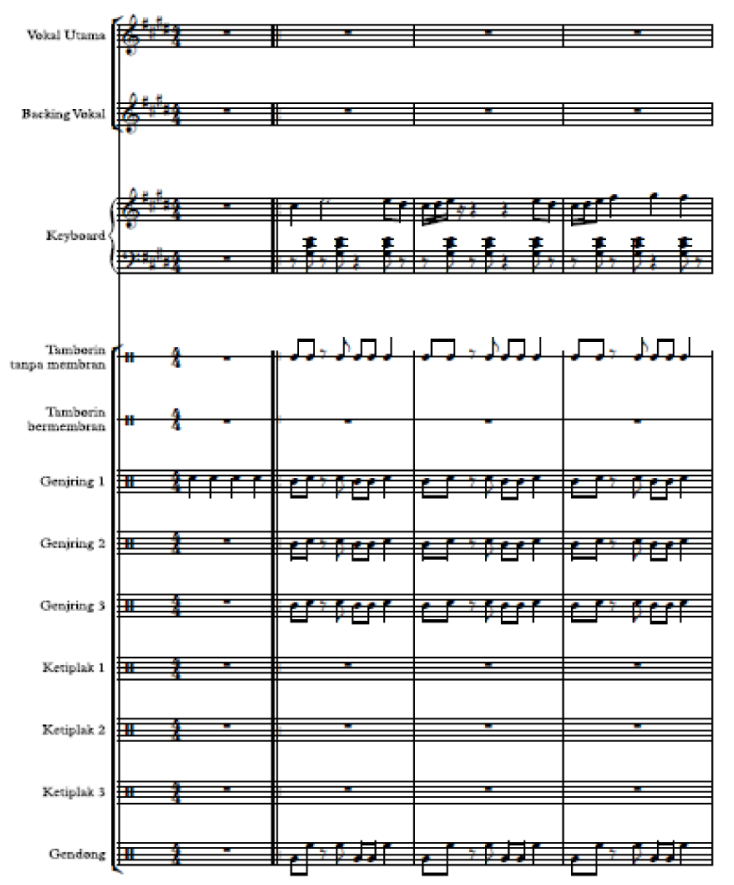

Gambar 9 : Intro Pada Lagu An Nabi (Dok. Afiin F M, 2019)

Selanjutnya bagian A $\square$ merupakan tema lagu yang sama dengan bagian A namun terdapat variasi pada backing vokal dan adanya transisi permainan dari instrumen ketiplak ke insturmen genjring mulai birama 20 sampai birama 28. Setelah itu masuk menuju interlude dimana vokal dan keyboard memainkan melodi utama, lalu terdapat variasi pola iringan pada instrumen genjring dan gendong dari birama 29 sampai birama 43. Pada bagian B, vokal utama masuk menyanyikan melodi utama diiringi oleh instrumen ritmis serta keyboard yang memainkan akor dan menambahkan filler improvisasi dari birama 44 sampai birama 52 .
Lagu An Nabi terdapat coda setelah pengulangan 2 (dua) kali dari bagian B menuju bagian A $\square$ hingga ending di coda. Pada coda vokal dan keyboard memainkan melodi utama untuk menutup lagu dari birama 53 sampai birama 59 dan terdapat variasi permainan pada instrumen genjring dan gendong. Menurut hasil wawancara dengan Bapak Agus Sumanto selaku pelatih dan pemain grup musik rebana Al-Istiqomah (10 Juni 2018).

"paling istimewanya ada pada pola iringan genjringnya ya mbak, disini saya buat 3 genjring supaya banyak variasinya. Biasanya kalo grup rebana ibu-ibu itu paling genjringnya cuma satu trus terakhir yang gampang diapali itu aransemennya mbak. Hampir di semua lagu saya aransemen di bagian intro, interlude sama ending itu polanya sama khususnya di genjring sama gendong karena supaya mudah dan gampang dihafal orang-orang."

Setelah dilakukannya analisis dari ketiga lagu yang dimainkan oleh grup rebana AlIstiqomah, peneliti dapat menemukan beberapa karakteristik yang terdapat pada pola iringan rebana dalam grup Al-Istiqomah yaitu terdapat 3 (tiga) macam pola iringan pada instrumen genjring. Ketiga macam pola iringan tersebut tidak dapat dimainkan dalam satu lagu, sehingga setiap satu lagu yang dimainkan hanya dapat memainkan salah satu macam pola iringan genjring saja, seperti pada lagu Ya Wazir instrumen genjring memainkan pola iringan B, lagu Sholawat Badar memainkan pola iringan genjring $\mathrm{A}$, dan lagu An Nabi instrumen genjring memainkan pola iringan $\mathrm{C}$. Hal tersebut dapat menjadi suatu karakteristik dalam pola iringan rebana Al-Istiqomah.

Karakteristik lain yang ada pada pola iringan rebana dalam grup Al-Istiqomah yaitu pada aransemen lagu yang memiliki ciri khas yaitu terdapat variasi pola iringan yang sama pada instrumen genjring dan gendong terutama pada saat intro, interlude, dan coda. Oleh karena itu, hampir semua lagu yang dimainkan selalu menggunakan variasi permainan tersebut untuk dijadikan ciri khas grup rebana Al-Istiqomah. 


\section{KESIMPULAN}

Karakteristik pola iringan rebana dalam grup Al-Istiqomah terbagi menjadi 2 (dua) macam. Pertama, terdapat 3 (tiga) macam pola iringan pada instrumen genjring yang berbeda yaitu pada pola iringan A pola ritmis genjring birama 2 (dua) di ketukan ke 2 (dua) up terdapat notasi $1 / 16$. Pada pola iringan $\mathrm{B}$ pola ritmis genjring disemua ketukan up terdapat notasi $1 / 16$, dan pada pola iringan $\mathrm{C}$ pola ritmis genjring di ketukan pertama up dan ketiga up terdapat notasi $1 / 16$ serta setiap lagu yang dimainkan hanya dapat memainkan satu macam pola iringan saja.

Kedua, adanya variasi pola iringan instrumen genjring, gendong, tamborin tanpa membran, dan keyboard pada intro, interlude, dan coda, serta adanya variasi pola iringan instrumen ketiplak pada pemain ketiplak 1 pada bagian B atau tema lagu II hampir di semua lagu yang diaransemen oleh pak Agus Sumanto. Selain itu juga terdapat pembagian suara antara vokal utama dan backing vokal pada bagian $\mathrm{A} \square$ atau variasi tema I di semua lagu yang dimainkan oleh grup rebana AlIstiqomah.

Adapun terdapat beberapa saran daripenulis yaitu hendaknya grup rebana Al-Istiqomah dapat menambahkan beberapa variasi-variasi atau aransemen di setiap lagu yang dimainkan supaya tidak monoton dan lebih menarik. Sebaiknya setiap lagu yang diaransemen oleh grup rebana Al-Istiqomah dibuat teks partitur pada setiap instrumen supaya pemain tidak mudah lupa dan memiliki arsip ketika nanti ada regenerasi pemain.

\section{DAFTAR PUSTAKA}

A Thoifin, N Huda. 1992. Kamus Pendidikan Pelajar dan Umum. Solo: CV. Aneka.

Banoe, Pono. 2003. Kamus Musik. Yogyakarta: Kanisius.

Faridan, Yusuf Nisfi. 2012. Karakteristik Pupuh Kinanti Kawali. Yogyakarta: Universitas Negeri Yogyakarta.

Jamalus. 1988. Pengajaran Musik Melalui Pengalaman Musik. Jakarta: Depdikbud Dikti.
Jaelani, Bisri M. 2007. Ensiklopedi Islam. Yogyakarta: Panji Pusaka.

John, Alfred. 2010. Membangun Karakter Tangguh. Cetakan ke-1. Surabaya: PORTICO Publishing.

Joseph, Wagiman. 2005. Teori Musik 1. Semarang:Universitas Negeri Semarang.

M. Miller, Hugh. 2017, Apresiasi Musik. Yogyakarta : Thafa Media Yogyakarta.

M. Soeharto. 1978. Kamus Musik Indonesia. Jakarta. PT. Gramedia Widiasarana Indonesia.

Maryaeni. 2005. Metode Penelitian Kebudayaan. Jakarta : PT Bumi Aksara.

Myers, Arnold, Clive Greted, Murray Campbell. 2004. Musical Instruments History, Technology, \& Performance of Instruments of Western Music. New York : Oxford University Press Inc.

Noviyanti, Siti Risa., Sutiyono, S. 2017. Bentuk, Perubahan Fungsi, dan Nilai-nilai Edukatif pada Musik Tari Japin Tahlul di Amuntai. Imaji: Jurnal Seni dan Pendidikan Seni, Vol. 15, No. 1, 97-112.

Prier sj, Karl Edmund. 1991. Sejarah Musik Jilid 1. Yogyakarta: Pusat Musik Liturgi.

Risang Ayu, Miranda. 1996. Problem Pengembangan Seni Kontemporer Islam. Jakarta: Yayasan Festival Istiqlal.

Suseno, Dharmo Budi, 2005. Lantunan Shalawat + Nasyid. Yogyakarta: Media Insani.

Sutiyono. 2014. Seni Tradisi di Indonesia dan Fenomena Haram-Halal. Imaji: Jurnal Seni dan Pendidikan Seni, Vol. 12, No. 2, 91-102.

Sutiyono. 2015. Social Action of Conversion in Islamic Art: Study on the Larasmadya Art Form in the Sleman Geocultural Region Sutiyono. Indonesia Journal of Geography, Vol. 47, No. 1, 77-87.

Tambajong, Japi. 1992. Ensiklopedi Musik Jilid I. Jakarta: PT. Cipta Adi Pustaka. 